$\underline{\text { Review Article }}$

\title{
EVOLVING ROLE OF CAR T-CELL IN CANCER IMMUNOTHERAPY
}

\author{
AMAL A. SULAIMAN ${ }^{*}$, ZAINAB AMER AI-SHAMAA ${ }^{2}$, MOHAMMAD EMAD AI-ASSADI ${ }^{2}$ \\ 1Department of Therapeutics and Clinical Pharmacy/Faculty of Pharmacy/Baghdad College for Medical Sciences/Baghdad, Iraq, \\ ${ }^{2}$ Graduated pharmacy students \\ Email: amal3_@yahoo.com
}

Received: 13 Aug 2019, Revised and Accepted: 14 Oct 2019

\begin{abstract}
Safety profiles of newly developed anti-cancer therapies is the main goal for efficient treatments to improve survival rates. Therefore, continuous efforts carried out to develop a therapeutic strategy with better outcomes. The concept of immune-oncology, which utilizes and enhances the capacity of human immune system was developed as an eventual opportunity to enhance remissions and limit the relaps of the disease. Later progression of cellular immunetherapies involve the introduction of genetically engineered $\mathrm{T}$ cells having chimeric antigen receptors (CARs) that embraced an antibody-derived antigen recognition domain connected to an internal T-cell signaling domain, so can recognize their targets with high degree of tumor selectivity. This approach showed vigorous antitumor outcomes and full recovery in end-stage patients suffering from liquid cancers as leukemia and lymphoma. However, still there is a challenge for bringing genetically modified T-cell immunotherapy to many patients with different tumor types including solid tumor. On other hand, studies indicated the potential to broaden T-cell-based therapies and foster for other possible applications beyond oncology as organ transplantation and autoimmunity. Therefore, this review aimed to illustrate the clinical applications, challenges, and approaches for more efficient clinical employment of CAR T cell therapies.
\end{abstract}

Keywords: Cancer, Immunotherapy, CAR T cells

(c) 2019 The Authors. Published by Innovare Academic Sciences Pvt Ltd. This is an open-access article under the CC BY license (http://creativecommons.org/licenses/by/4.0/) DOI: http://dx.doi.org/10.22159/ijcpr.2019v11i6.36351

\section{INTRODUCTION}

Over the past decades, increased evidence howed that the use of traditional cytotoxic strategies in the management of neoplastic disease showed a marked drawback because of their low selectivity and development of drug-resistance cancer cells [1-3]. Moreover, the lack of an efficient approach to completely eleminate malignant cells rise the need for more effective therapies. Recently, the concept of cancer immune therapy has been emerged as a new challenging pathway that alters the features of cancer treatment. Where, they get use of normal ability of the immune system in treatment of sever illness as cancer $[4,5]$. However, the cellular immunotherapies that bind and augment the natural capacity of the immune system to fight cancer has been investigated for treatment of human immunodeficiency and tumor [6, 7]. The principle of covey the immune response to combat tumor based on understanding the interplay between cancer and immune sysrem that often involve the following interactions; i) Initial recognition of "nonself " antigens from invading pathogens or infected/malignant cells; ii) selective attacks and destroys of causative agents whith out affecting the normal host cells; and finally iii) establishing an immunological memory mediated by adaptive immune system to provide a protection against further attack of the host [8-10]. This sequence of organized step-wise events commonly named (cancer immunity cycle), through which the immune system acquired properties that induce an immune reaction called immunoediting, which provides a balance between immune surveillance and cancer progression [11, 12]. Immunoedting comprised three primary phases: elimination, equilibrium, and escape that often contribute to cancer elimination, dormancy, and progression, respectively $[13,14]$. Interestingly, this capacity of cancers to evade the immune response is now recognized as one of the most characterstic cancer hallmarks, that provides the platform for treatments within the milieu of immunotherapies $[15,16]$. In this regard, this study concerned with later findings in cell immunotherapies that developed as a potential therapeutic intervention for cancer treatments.

\section{Cancer immunotherapy}

An accumulated evidence indicated that both immune systems and cancer cells are often present in a state of dynamic balance producing an immune response which either eradicates tumor cells or offers a chance for tumor to escape immunologic elimination [17]. Accordingly, various therapeutic strategies have been developed, by which the immune system possess anticancer effect as immunostimulants, Monoclonal antibodies, Autograph or allograph transfer of lymphocytes, cancer vaccines and immunomodulators. However, the common impact of cancer immunotherapies is to reactivate the immune system to easily recognize tumor cells again, and inducing an immune-mediated control of cancer, either through either a passive or active processes conferring direct lysis of cancer cells $[18,19]$. For passive type, the machineries of the host immune system were utilized to target and combat tumor antigens as with the use of, tumor-targeting monoclonal antibodies (mAbs), cytokines like Interleukins (IL-2, IL-12), Interferon's (IFNs) and in some approaches they use adoptively transferred $\mathrm{T}$ cells. These treatments usually possess an intrinsic antineoplastic activity. On the other hand, the active immunotherapy aimed to boost the host's immune system to defend against cancer, as with the use of checkpoint inhibitors or different types of anticancer vaccines, including (cell-based, peptide or protein-based, gene therapy-based, idiotype immunoglobulin based and autologous or allogeneic WholeTumour-Cell)vaccines. Where their anticancer properties employed only upon engagement with the host immune system. [20]. While, later classification based on treatment specificity against tumor antigen, where, the nonspecific immunotherapy make use of cells or substances that are not directed to a specific antigen as with immunostimulatory cytokines or checkpoint blockers which are activated broad specifity of anticancer immune responses [21]. Conversly, instructing the immune system to generate a $\mathrm{T}$ cell response against tumor-specific antigen (TSA), or tumor-associated antigens (TAAs) that are presented by specilazied APC denoted as active specific immunotherapy $[22,23]$.

\section{Adoptive cell therapy (ACT)}

A strategy of immunotherapy was directed for the treatment of progrssed tumor. This can be done by manipulation of patient's own T-cells ex vivo, so can fight the diseases; effectiveness of this strateegy usually based on the availability of sufficient number of active antitumor $\mathrm{T}$ cells named as adopted T cells (ACT) to efficiently regress cancer [24]. In this strategy a particular variant of cell-based 
anticancer immunotherapy was utilized to involve; the identification and collection of circulating $\mathrm{T}$ lymphocytes of patient have antitumor activity called tumor-infiltrating lymphocytes (TILs); after selection, cells exposed to modification/expansion and grown ex vivo up to 1011, and subsequently further activation step carried to give high avidity recognition by tumor antigen-presenting cells together with release of in vivo inhibitory factors. Finally, the activated cells infused back to the same patient to provide a favorable microenvironment that better supports antitumor immunity $[23,25]$. To perform these steps, the patients may experience a condition known as lymphodepletion by the use of chemotherapy or irradiation to counteract the immunosuppressant effect of regulatory $\mathrm{T}$ cells (Treg), as well as to minimize the competitive effects of other lymphocytes with the transferred cells for various factors involved in T-cell survival like growth factors or interleukins 2, 7 and 15 (IL2. IL7 and IL15) [26].

Clinically, they use of (young TIL) as an alternative strategy for ACT, where young lymphocytes isolated from patients allowed to grow up for short term ex vivo, then reintroduced again into the patient. This approach of immunotherapy provides about 56\% regression of variety of cancer including those of bone, liver, brain and lymph nodes [27]. Although, the use of lymphocytes expanded from a tumor biopsy sample, and endogenous antigen-specific $\mathrm{T}$ cell from peripheral blood are hopeful and efficient immunotherapeutic regime, but the inaccessible tumor sites, poor TIL recovery, poor antigenicity of some tumors, and the demanding of intensive laboratory applications make the treatment hard to produce and roadblocks the expanding of TIL therapy as a global cancer therapy option. However, the main issue with ACT is the fact that it is a highly personalized treatment where a new and different reagent has to be created each time for each patient. It relies on activated cells with lowered triggering thresholds for clinical benefit but does not enrich for TAA specific T-cells [28]. Therefore, third strategy has been developed to improve the therapeutic potential of ACT. For instance, genetic engineering has been employed to endow peripheral blood lymphocytes (PBLs) with features such as unique antigen specificity, increased proliferative potential and persistence in vivo for developing TAA specific T-cells is to engineer them with artificial TAA-specific receptors e. g. a new TCR or a chimeric antigen receptor (CAR) [26, 29].

\section{Genetically modified $t$ cells in cancer therapy}

$\mathrm{T}$ cells or ( $\mathrm{T}$ lymphocytes) widely distributed within tissues and tumor environments. They play an essential role in cell-mediated immunity and involve in long-lasting antigen-specific effector and immune memory responses. Usually, $\mathrm{T}$ cells expressed $\mathrm{T}$ cell receptors (TCRs) on their surface providing a single antigen-binding site. The TCR consists of two chains: the alpha $(\alpha)$ and beta $(\beta)$ chains. Both chains have a constant region (c) and a variable region (v), and it is the variable region that confers antigenic specificity on the T cell, moreover, TCR associated with the CD3 complex, which

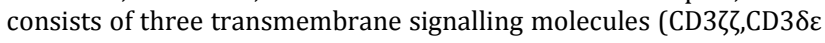
and $C D 3 \gamma \varepsilon$ ). Accordingly, TCR specificity aid in recognition of an antigen ligand comprising a short contiguous amino acid sequence of a protein presented on the target cell by a major histocompatibility complex (MHC-1 for cytotoxic T cells). Efficient Tcell activation also requires the simultaneous binding of the $\mathrm{T}$ cell co-receptor (CD8 for cytotoxic T cells). ss, disulphide bridge [30,31]. Previous studies indicated that the use of infiltrating T cells (TIL) after being isolated from tumor tissue, cultivated, activated and expanded ex vivo, then re-infused provided a promising efficacy to induce long-lasting regression in patients with metastatic melanoma [32-38]. As well as improved prognosis in other cancer types, including ovarian, colon, and breast cancer tumor in clinic [30, 3941]. However, there some difficulties limited the use of this strategy as the a difficulty in isolating tumor-specific $\mathrm{T}$ cells from many cancer patients; and the long-time consumed to gain a therapeutic amount of tumor-specific $\mathrm{T}$ cells. In addition tolerance has been reported [42], since the specificity of TCR was intrinsically controlled due to its dependence on antigens expressed by tumors via their MHC complexes [43]. To overcome limitations associated with tolerance, the research was directed toward utilization of genetically modified $\mathrm{T}$ cells which redirected to successfully target specific antigens expressed by tumors. In particular, T cells were engineered to express modified TCRs (so-called TCR therapies) or protein-fusion derived chimeric antigen receptors (CARs) that have enhanced antigen specificity, producing more efficient $\mathrm{T}$ cells for targeting tumors without the requirement for de novo T-cell activation in the patient. [31]. So that the introduction of this approach allows sufficient production of antigen-specific $\mathrm{T}$ cells. Moreover, in clinical situation the use of engineered T cells in cancer treatment showed remarkable successes in patients with colorectal carcinoma, synovial sarcoma, metastatic melanoma, and multiple myeloma. Hence, for successful generation of tumor-specific TCR, initially a suitable target sequence must be identified, which either isolated from tumor-reactive $\mathrm{T}$ cell or, if not possible, using alternative technologies to get a highly active anti-tumor T-cell antigens, by one of the following [44-50].

1) Immunization of experimental transgenic animals with human tumor protein to produce $\mathrm{T}$ cells expressing TCRs against human antigens.

2) Isolation of tumor-specific $T$ cells from a patient showing tumor remission and the reactive TCR sequences then conveyed to T cells obtained from another patient who has a disease but not-responsive. This called Allogenic T cell transfer approach.

3) Intensify the killing reactivity of $T$ cells against tumor and rising the potential interaction of a feebly reactive tumor-specific TCR with target antigen by in vitro alteration of the TCR sequence [51].

\section{Chimeric antigen receptors (CARs)}

The Chimeric antigen receptor (CAR) T-cell therapy was developed to use gene transfer technology for reprogramming patient's T cells to express CARs that directed the cytotoxic potential of $\mathrm{T}$ cells against tumor that would otherwise be ignored [3]. The CARs are an engineered fusion proteins that contain an extracellular antigenbinding domain composed of a single-chain variable fragment derived from an antibody and intracellular signaling domains, which are involved in the initiation of T-cell signaling and downstream Tcell effector functions $[4,52]$. The interest and investment in the development of CAR T-cell therapy is rapidly increasing in both academia and industry, with multiple ongoing clinical trials as well as many expectations for the future of the field. Although CAR T-cell therapies are on a fast track to approval by the US Food and Drug Administration for B-cell malignancies, there is active investigation into building better CAR T cells for treating hematologic malignancies and solid tumors. The technique of Gene-transfer was known in 1990s and called "T body approach". Nowadays these artificial lymphocyte signaling receptors were restructured the specificity of T cells that commonly referred to as chimeric immune receptors (CIRs) or chimeric antigen receptors (CARs). Where, TCR part is replaced by CAR which includes two domains: an extracellular derived from tumor-specific antibody single-chain fragment (scFv) having specificity against a cell surface antigen and an intracellular signaling domain [53, 54] (fig. 1).

Genes encoding these receptors are inserted into patient's T cells using viral vectors to generate tumor-reactive T cells. While, the intracellular domain includes fused signaling domains from a natural TCR complex and costimulatory molecules. In general, CAR cells are essentially engineered cytotoxic T lymphocytes to target specific tumor cells, and they combined both antibody-like recognition with T-cell activating function [55]. These novel receptors initiate a functional downstream effector T-cell signaling pathway when they encounter target antigen, usually the TAA on a cancer cell. This gives the opportunity to engineer a large variety of TAA-specific receptors targeting a broad range of cancer types [56]. Once infused, CAR T cells engraft and undergo extensive proliferation in the patient. Each CAR T cell can kill many tumor cells, and may promote immune surveillance to prevent tumor recurrence through antigen release, by assisting tumor-infiltrating lymphocytes to attack tumors, or by their own persistence [57]. In other wards, CAR T cells hold antitumor activity through immunemediated communication with target cells through the secretion of proinflammatory cytokines as interferon [IFN]- $\gamma$, and [IL-2] augumenting an endogenous immune response and partly by expression of pro-apoptotic ligands and release of perforin. In addition, CAR T cells involve in "serial killing" (i,e; ordered destruction of target cell) [58]. 


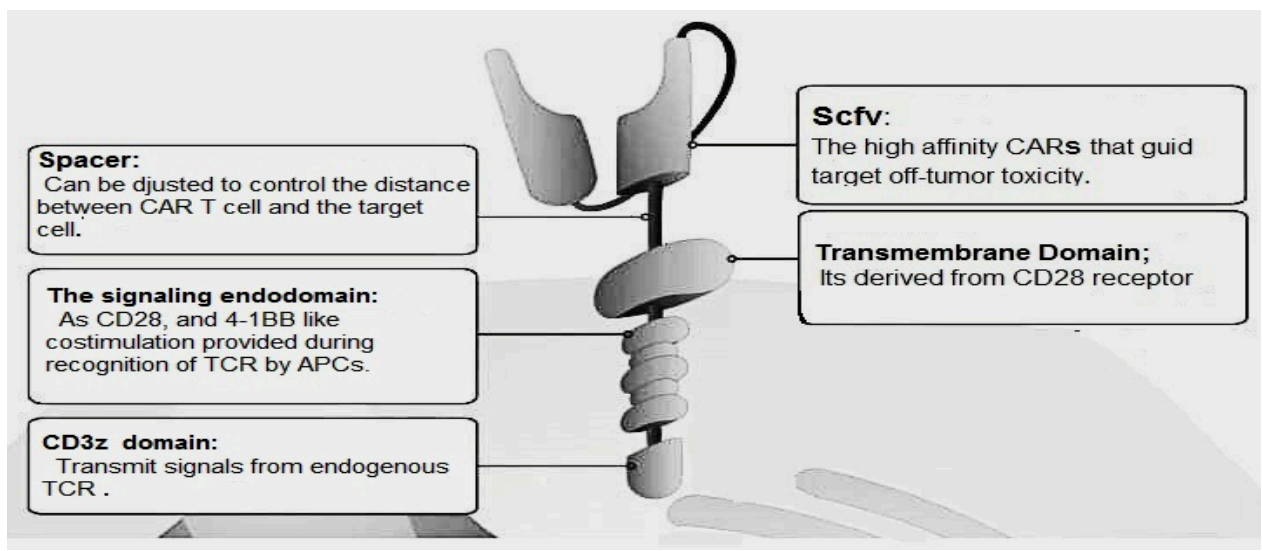

Fig. 1: Shows the CAR, which includes a single-chain variable fragment (Scfv) that binds to tumor antigens, fused to a spacer and transmembrane domain. The intracellular domain contains costimulatory domains, such as CD28 and 4-1BB and CD3z chain, which drive signal activation and amplification of CAR $T$ cell

\section{Generational construction}

As a promising therapeutic regimen, CAR-T cell therapy has stood the test of time for many years to improve the effectiveness and safety of this approach. CAR design has developed over the past few decades as shown in (fig. 2), and now a days four different generations are available varies in the intracellular sections.

\section{First-generation}

The basic structures of CARs which known as first-generation CARs, (lack of costimulatory signal), and consist of a T-cell activating domain (typically including the chain of the CD3 complex) and extracellular immunoglobulin-derived heavy and light chains to direct specificity. This generation recognize antigen independently of human leukocyte antigen (HLA) but do not direct sustained T-cell responses, owing to their limited signaling capability. This generation of CARs transmitted activating signals only via signaling chains like ( $\mathrm{CD} 3 \zeta$ or $\mathrm{F} c \varepsilon \mathrm{RI} \gamma$ ), licensing the engrafted $\mathrm{T}$ cells to eliminate tumor cells $[59,60]$.

\section{Second generation}

Second-generation CARs contain an additional costimulatory domain (CM I), predominantly the CD28 domain (fig. 2). Signaling through these costimulatory domain leads to enhanced proliferation, cytokine secretion, and afford anti-apoptotic functions in human primary $\mathrm{T}$ cells, and renders engrafted $\mathrm{T}$ cells resistant to immunosuppression paved the way for dual-signaling CARs that could effectively direct the expansion of functional $\mathrm{T}$ cells on repeated exposure to antigen $[61,62]$. This generation enabled the production of the persistent "living drugs" that are the foundation of current CAR T-cell therapy. Both first and second generations showed clinical efficacy $[63,64]$.

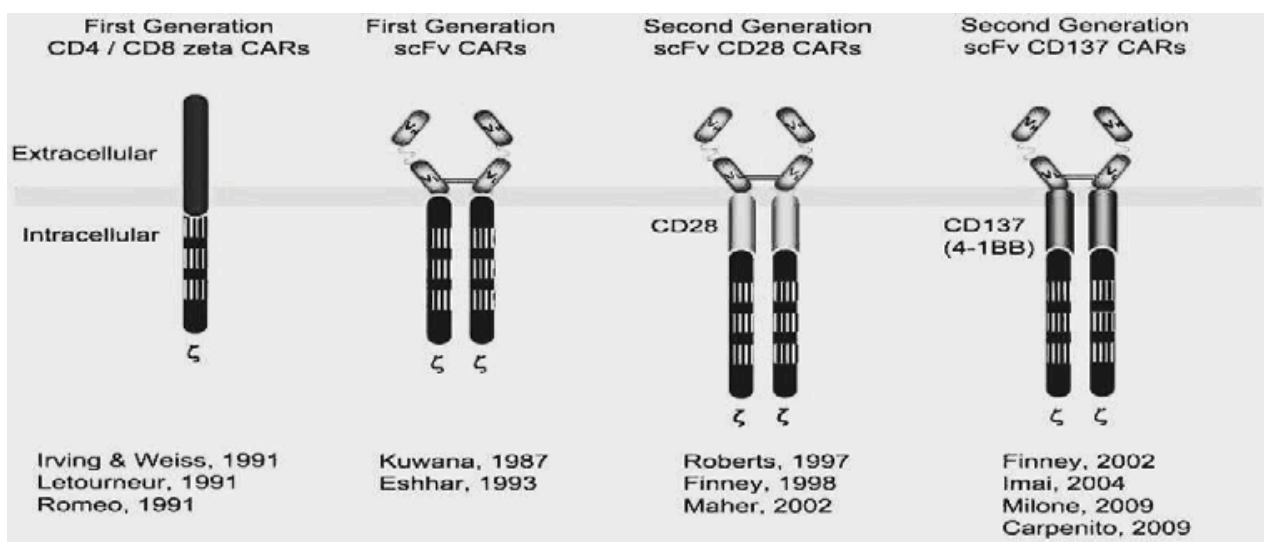

Fig. 2: A drawing of CAR T cells. Showing that 1st generation possess CD3zeta chain, or other comparable signaling domains. While $2^{\text {nd }}$ generatione hav CD28 or CD137 signaling domains as they were originally described by Kuwana and Helene Finney

\section{Third generation}

Recent developments fused the intracellular part of a second costimulatory molecule (CM II) in addition to CD28 and Immunoreceptor tyrosine-based activation motif ITAM-bearing signaling chains of previous generations, thus generating tripartite signaling CARs. T cells engrafted with third-generation CARs seem to have superior qualities regarding effectors function and in vivo persistence indicating that CD28 based end domains can mediate constitutive signaling leading to terminal differentiation of effector $\mathrm{T}$ cells [65-67]. In general, second, third and fourth generations possess the signaling endo-domains of costimulatory molecules like CD28, CD134 (OX40) or CD137 (4-1BB), which are fused with CD3z, as shown in [fig. 3]. This structure imitates the costimulation signal when TCR combines with antigen-presenting cells to complete the process of activation.

Subsequent to the engagement of CAR T-cell antibody/ligand with target cell surface antigen, the genetically redirected $\mathrm{T}$ cell causing target cell cytolysis by release of cytotoxic granules containing perforin and granzymes to lyse the target cell, including drug-resistant tumor cells. A second cytolytic mechanism involves the interaction between Fas receptor (FasR/CD95) on the target cell and Fas ligand (CD95L) on the CD8p T cell. When the Fas ligand and receptor are engaged, signaling pathways are activated in the target cell that trigger a caspase cascade resulting in target cell death $[68,69]$. 


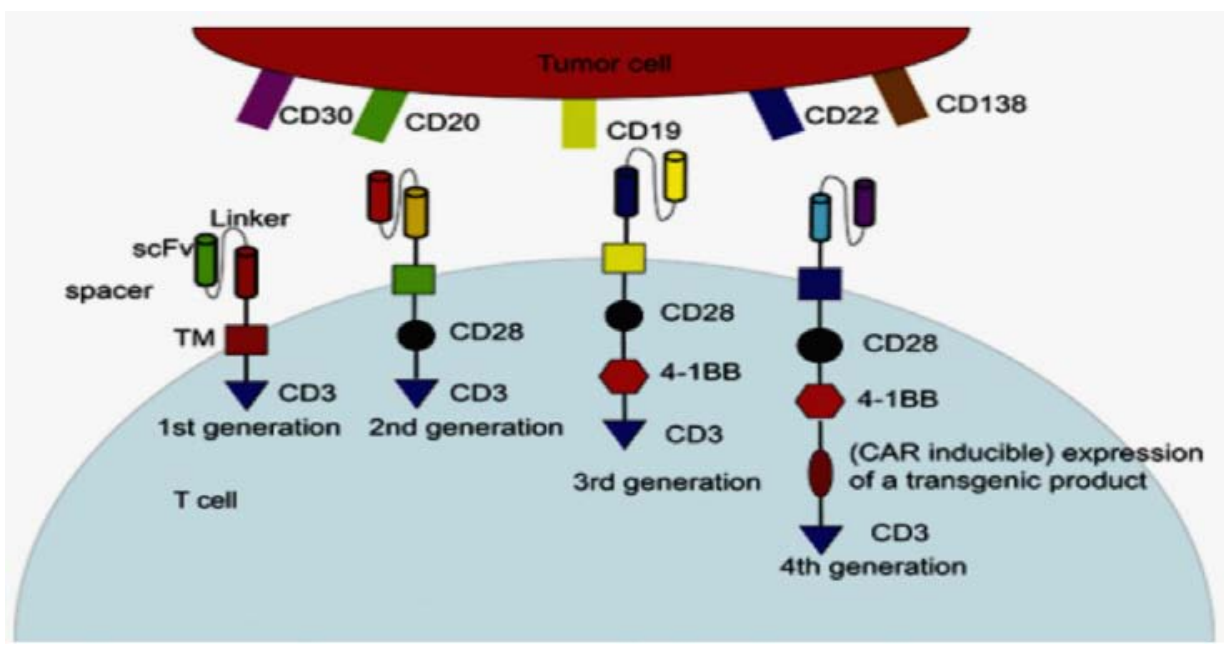

Fig. 3: Basic structure of 4 generations of (CAR-T cell) and common targets on tumor cells, showing the differences in their intracellular segments which have one or several fused signaling domain(s) from natural TCR complex and costimulatory molecules. scFv, single-chain fragment. TM, the transmembrane region

\section{CAR T cells for B-cell malignancies}

The optimal target for a CAR T-cell strategy would be a tumor type that expresses an antigen unique to that tumor and that is absent from nontumor tissue. For this reason, B-cell malignancies were the initial cancer type to become the focus of a series of clinical trials. The CD19 surface protein is a B-cell marker that is expressed on essentially all B cells, from pro-B cells to memory B cells, but not on hematopoietic stem cells. Moreover, patients appear to be able to sustain persistent reduction in numbers and function of CD19 B cells, providing that immunoglobulin replacement therapy is established. A single infusion of human peripheral-blood T cells engineered with a CD19-specific CAR was shown to eradicate established lymphomas and leukemias in mice. While, clinical trials have emerged that target a range of CD19 B-cell malignancies, including non-Hodgkin lymphoma, chronic lymphocytic leukemia, acute lumphoblastic leukemia [70-73]. Tumor regression correlates well with CAR T-cell proliferation in vivo and release of cytokines. Lympho-depleting preconditioning helps proliferation and persistence of CAR T-cells in some patients, which may be associated with elimination of immune suppressive cells like Tregs and increase in levels of cytokines IL-15 and IL-7 that enhanced expansion of infused T-cells and persistence of T-cells with a central memory phenotype.

The largest published series to date treating adults with relapsed or refractory B-ALL with CD19-targeted CAR T-cells are summarized in table 1.

Table 1: Clinical features of CAR T-cell of published clinical data that investigating CD19-targeted CAR T-cells in the treatment of B-ALL

\begin{tabular}{|c|c|c|c|c|c|c|}
\hline $\begin{array}{l}\text { Institution/ } \\
\text { Reference }\end{array}$ & $\begin{array}{l}\text { No. of } \\
\text { patiens } \\
\text { reported }\end{array}$ & ScFv & $\begin{array}{l}\text { Costimul- } \\
\text { atory } \\
\text { domain }\end{array}$ & $\begin{array}{l}\text { Lymphodepleting } \\
\text { chemotherapy }\end{array}$ & $\begin{array}{l}\text { CAR T-cell } \\
\text { doses }\end{array}$ & Disease-related outcomes \\
\hline $\begin{array}{l}\text { Memorial Sloan } \\
\text { Kettering Cancer Center } \\
\text { Brentjens et al. } 2013 ; \\
\text { Davila et al. } 2014 ; \\
\text { Park et al. } 2018 .\end{array}$ & 53 & SJ25C1 & CD28 & Cy or Cy/Flu & $\begin{array}{l}1 \times 106 \mathrm{vs} \\
3 \times 106 \\
\text { CAR+ } \\
\text { T-cells } / \mathrm{kg}\end{array}$ & $\begin{array}{l}\text { CR: } 83 \% \text { (MRD-negative } \\
\text { in } 67 \% \text { ); } 17 \text { of } 44 \text { in CR underwent allo- } \\
\text { HSCT Median EFS: } 6.1 \text { mo (all) and } 12.5 \\
\text { mo (pts in MRD-negative CR) }\end{array}$ \\
\hline $\begin{array}{l}\text { Fred Hutchinson Cancer } \\
\text { Research Center Turtle } \\
\text { et al. } 2016 .\end{array}$ & 30 & FMC63 & $4-1 \mathrm{BB}$ & $\begin{array}{l}\text { Cy } 2-4 \mathrm{~g} / \mathrm{m} 2 \\
( \pm \text { etoposide } 100 \\
\mathrm{mg} / \mathrm{m} 2 \times 3 \mathrm{~d}) \text { or } \\
\text { Cy } 30-60 \\
\mathrm{mg} / \mathrm{kg}+\text { Flu } 25 \\
\mathrm{mg} / \mathrm{m} 2 \times 3-5 \mathrm{~d}\end{array}$ & $\begin{array}{l}2 \times 105 \\
2 \times 106, \text { and } \\
2 \times 107 \\
\text { CAR+ } \\
\text { T-cells } / \mathrm{kg}\end{array}$ & $\begin{array}{l}\text { CR: 10/12 (MRD-negative by flow } \\
\text { cytometry) among pts receiving Cy or } \\
\text { Cy/etoposide; } 16 / 17 \text { (MRD-negative by } \\
\text { flow cytometry and FISH/karyotype) } \\
\text { among pts receiving Flu/Cy Median DFS: } \\
\text { not yet reached in Flu/Cy arm }\end{array}$ \\
\hline $\begin{array}{l}\text { University of } \\
\text { Pennsylvania Frey et al. } \\
2014 .\end{array}$ & 12 & FMC63 & $4-1 \mathrm{BB}$ & $\begin{array}{l}\text { Investigator's } \\
\text { choice }\end{array}$ & $\begin{array}{l}6.5- \\
8.45 \times 106 \\
\text { CAR+ } \\
\text { T-cells/kg }\end{array}$ & $\begin{array}{l}\text { CR: } 89 \%(8 / 9) \text { of evaluable pts, all MRD- } \\
\text { negative; } 3 \text { non-evaluable patients died } \\
\text { in the setting of refractory CRS }\end{array}$ \\
\hline $\begin{array}{l}\text { National Cancer } \\
\text { Institute } \\
\text { Brudno et al. } 2016 .\end{array}$ & 5 & FMC63 & CD28 & $\begin{array}{l}\text { None } \\
\text { (administered } \\
\text { following allo- } \\
\text { HCT) }\end{array}$ & $\begin{array}{l}4.2-7.1 \times 106 \\
\text { CAR+ } \\
\text { T-cells } / \mathrm{kg}\end{array}$ & $\begin{array}{l}\text { CR: } 80 \% \text { ( } 4 / 5 \text {, all } \\
\text { MRD-negative) }\end{array}$ \\
\hline
\end{tabular}

Cy: cyclophosphamide, Flu: fludarabine, EFS: event-free survival, DFS: disease-free survival, CR: complete response, MRD: minimal residual disease, Allo-HCT: allogeneic hematopoietic cell transplantation.

\section{Clinical applications of CAR T cells}

\section{CAR-T cell therapy in acute lymphoblastic leukemia}

The clinical evaluation of CAR therapies has grown exponentially, with the majority evaluating the treatment of B-cell cancers. During the treatment of acute lymphoblastic leukemia (ALL), it has been found that the most effective CAR is that posses anti-CD19, which highly expressed in B-ALL to be an important target as well as antiCD20 and immunoglobulin light chains serve as a potential target $[73,74]$. CD19 is a specific protein that regulates B lymphocytes 
activation and is expressed throughout all stages of B cell differentiation. It was reported that more than 1000 patients have received CD19-targeted CAR T cells, and reported data for adults and children have B-ALL. Showed promising complete remission (CR) and partial remission (PR) rates. [75, 76].

A clinical study, in which CD19 CART cells were infused following to (cyclophosphamide), revealed that 15 out of 16 patients need a qualified amount of T cells; and the CR rate was about 88\% [77]. Other Studies involving children and young adult patients with age range between (1-30 y old) have found that the CR rate for the $20 \mathrm{~B}$ ALL patients was 70\%. [78]. recently, the CD22 has been recognized as a target for CAR T cells to overcome the limitation of anti CD19 therapy [79].

\section{CAR-T cells therapy in chronic lymphocytic leukemia (CLL)}

Currently, the only approach for the treatment of CLL is stem-cell transplantation. [80]. However, number of preliminary clinical data of CD20-and CD19-targeted CAR T-cells for B-cell non-Hodgkin lymphoma, and CD19-targeted CAR T-cells for CLL later introduced as treatment for relapsed or refractory patients and those with high risk (table 2). Some responses to the CAR-T cell in CLL patients reported equal CR and PR rates. [81-83]. Unfortunately, the pathogenesis of CLL known to induce an early suppression of immune function, therefore the efficacy of CAR-T cell therapy suggested to be hurdeled by impairment of $\mathrm{T}$ cells expansion ex vivo that isolated from CLL patients as well as their proliferation in vivo. Because of that it's essential to identify an agent to enhance the ability to prevent such phenomenon [84].

Table 2: Clinical features of CAR T-cell of published clinical data that investigating CD19-targeted CAR T-cells in the treatment of CLL

\begin{tabular}{|c|c|c|c|c|c|c|}
\hline Institution & $\begin{array}{l}\text { No. of } \\
\text { patients } \\
\text { reported }\end{array}$ & ScFv & $\begin{array}{l}\text { Costimul- } \\
\text { atory } \\
\text { domain }\end{array}$ & $\begin{array}{l}\text { Lymphodepleting } \\
\text { chemotherapy }\end{array}$ & Infused cell doses & Responses observed \\
\hline $\begin{array}{l}\text { National Cancer Institute } \\
\text { Kochenderfer } \text { et al.2012 }\end{array}$ & 4 & FMC63 & CD28 & $\begin{array}{l}\text { Cy } 60 \mathrm{mg} / \mathrm{kg} \times 2 \mathrm{~d}+\mathrm{Flu} \\
25 \mathrm{mg} / \mathrm{m} 2 \times 5 \mathrm{~d}\end{array}$ & $\begin{array}{l}0.3-2.8 \times 107 \\
\text { CAR+T-cells/kg }\end{array}$ & $\begin{array}{l}\text { ORR: } 3 / 4(\mathrm{CR}, n=1 ; \mathrm{PR}, \\
n=2)\end{array}$ \\
\hline $\begin{array}{l}\text { National Cancer Institute } \\
\text { Kochenderfer et al. } 2015\end{array}$ & 4 & FMC63 & CD28 & $\begin{array}{l}\text { Cy } 60 \mathrm{mg} / \mathrm{kg} \times 1-2 \\
\mathrm{~d}+\text { Flu } 25 \mathrm{mg} / \mathrm{m} 2 \times 5 \mathrm{~d}\end{array}$ & $\begin{array}{l}1-4 \times 106 \text { CAR+ } \\
\text { T-cells } / \mathrm{kg}\end{array}$ & $\begin{array}{l}\text { ORR: } 4 / 4(\mathrm{CR}, n=3 ; \mathrm{PR}, \\
n=1)\end{array}$ \\
\hline $\begin{array}{l}\text { National Cancer Institute } \\
\text { Brudno et al. }\end{array}$ & 5 & FMC63 & CD28 & $\begin{array}{l}\text { None (administered } \\
\text { following Allo-HCT) }\end{array}$ & $\begin{array}{l}0.4-3.1 \times 106 \\
\text { CAR+T-cells } / \mathrm{kg}\end{array}$ & $\begin{array}{l}\text { ORR: } 2 / 5(\mathrm{CR}, n=1 ; \mathrm{PR}, \\
n=1 ; \mathrm{SD}, n=1)\end{array}$ \\
\hline $\begin{array}{l}\text { Fred Hutchinson Cancer } \\
\text { Research Center. Turtle et } \\
\text { al. } 2017\end{array}$ & 19 & FMC63 & $4-1 B B$ & $\begin{array}{l}\text { Cy } 30-60 \mathrm{mg} / \mathrm{kg} \times 1+ \\
\text { Flu } 25 \mathrm{mg} / \mathrm{m} 2 \times 3 \mathrm{~d}\end{array}$ & $\begin{array}{l}2 \times 105,2 \times 106, \text { or } 2 \\
\times 107 \text { CAR+ T- } \\
\text { cells } / \mathrm{kg} ; 1: 1 \\
\text { CD } 4+\text { :CD } 8+\end{array}$ & $\begin{array}{l}\text { ORR: } 14 / 19(\mathrm{CR}, n=4 \\
\text { PR, } n=10)\end{array}$ \\
\hline $\begin{array}{l}\text { University of Pennsylvania. } \\
\text { Porter et al. } 2015\end{array}$ & 14 & FMC63 & $4-1 B B$ & Investigator's choice & $\begin{array}{l}0.14-11 \times 108 \\
\text { CAR+T-cells (median, } \\
1.6 \times 108 \text { cells) }\end{array}$ & $\begin{array}{l}\text { ORR: } 8 / 14 \text { (MRD- } \\
\text { negative CR, } n=4 ; \text { PR, } n \\
=4 \text { ) Median PFS: } 7 \mathrm{mo} \\
\text { Median OS: } 29 \text { mo }\end{array}$ \\
\hline $\begin{array}{l}\text { University of Pennsylvania. } \\
\text { Porter et al. } 2016 .\end{array}$ & 35 & FMC63 & $4-1 B B$ & Investigator's choice & $\begin{array}{l}5 \times 107 \text { vs. } 5 \times 108 \\
\text { CAR+T-cells }\end{array}$ & $\begin{array}{l}\text { ORR: } 9 / 17 \text { (CR, } n=6 \text {; PR, } \\
n=3 \text { ) among pts } \\
\text { receiving } 5 \times 108 \text { CAR+ } \\
\text { T-cells }\end{array}$ \\
\hline
\end{tabular}

Cy: cyclophosphamide, Flu: fludarabine, OS: overall survival, PFS: progression-free survival, CR: complete response, PR: partial response, MRD: minimal residual disease, Allo-HCT allogeneic hematopoietic cell transplantation.

\section{CAR-T cell therapy in lymphoma}

CAR-T cells therapy was categorized among the most recent immunotherapies for relapsed conditions or chemotherapyrefractory B-cell non-Hodgkin lymphoma (NHL). [85, 86]. Preclinical in vitro and in vivo studies indicated effective antitumor activities of both second and third generation T cells, possessing CD28 or 4-1BB cytoplasmic signaling domains [87].

\section{CAR T cells adverse effects and toxicity}

The adverse effects are known to be associated with all cancer therapies, and CAR T cells are not an exception. Many of unwanted effects are reported with CAR T cells depend on the specificity of antibody single-chain variable fragments and T-cell activation. These effects are thus reversible when the target cell is eliminated or the engraftment of the CAR T cells is terminated. In some patients, they found that CAR $\mathrm{T}$ cells induce a clinical syndrome of fevers, hypotension, hypoxia, and neurologic changes associated with marked elevations of serum cytokine levels [88-90]. This spectrum of clinical and laboratory findings has been termed the cytokine release syndrome (CRS). For the investigation of cytokines, several studies surprisingly identified IL- 6 as a major cytokine induced by CAR therapy. Meanwhile, IL-6 also stems from apoptotic B cells o the occurrence of this syndrome is associated with both CD19 and B-cell maturation antigen (BCMA, also known as CD269).

Intense condition of CRS may be managed initially by using the IL- 6 receptor inhibitor tocilizumab, and when symptoms persist the addition of lymphotoxic corticosteroids is advised [84].

Other effects were observed after CAR T-cell infusion in both children and adults including the number of reversible neurologic symptoms as delirium, seizure-like activity, confusion, word-finding difficulty, aphasia, and frank obtundation. However, such symptoms found to be unrelated to CRS $(63,70,82,86)$.

\section{Advantages of CAR-T cell therapy}

The use of CARs to redirect $T$ cells specifically against TAAexpressing tumor cells provide an advantages over former classical adaptive immune T-cells. As they have a unique specificity and can eradicate cancer cells containing the corresponding TAAs. So this approach will by-pass unnecessary killing of healthy tissues. Moreover, in contrast to the long-lasting procedure of in vitro selection, characterization, and expansion of T-cell clones with native specificity for MHC tumor peptide complexes, genetic modification of polyclonal T-cell populations allows generating TAAspecific $\mathrm{T}$ cells in one to two weeks.

In addition, engraftment with CARs having flexible intracellular signaling domains enables $\mathrm{T}$ cells to MHC-independent antigen recognition; thus, major immune escape mechanisms of tumors such as downregulation of MHC molecules are efficiently by-passed. Furthermore, proliferation and survival of modified $\mathrm{T}$ cells can be improved by the achievement of a multitude of signaling domains from different immune receptors in a single CAR [91]. Besides that, CAR-T cells not require the aid of HLA expression for recognition of cell surface molecules, so they can avoid $T$ cell immune surveillance mediated by hiding HLA or other molecules involved in antigen processing and presentation [92]. It is valuable to point out that CAR-T cell can also identify the potential antigens in nearly all forms including carbohydrate, lipid, protein antigens, which can be combined specifically by antibodies [93].

\section{CONCLUSION}

The threshold of the golden era for adoptive T cell therapy, as advances in basic immunology have informed the development of a 
new field of synthetic immunology, which may increase the potency of approaches that target cancer.

Cancer immunotherapy using genetically engeneered $\mathrm{T}$ cells serves as a very promising future approach for incurable cancers therapy. CAR-T cell therapy, still considers as a newley evolving approach for treatment of refractory hematological malignancies especially ALL, CLL and lymphoma and some associated adverse effects become bottleneck to the widespread use of this approach. Although that all currently available clinical studies suggested the significance of costimulation and lymphodepletion and lymphodepletion in promoting effectiveness of CAR T-cells. But still there is an urgent need for mature data to achieve right conclusions about the optimal effectiveness and safety for this therapeutic strategy. That will give physicians and patients the information and therapeutics to eliminate these malignancies.

\section{AUTHORS CONTRIBUTIONS}

All the author have contributed equally.

\section{CONFLICT OF INTERESTS}

Declared none

\section{REFERENCES}

1. Norouzi S, Gorgi Valokala M, Mosaffa F, Zirak MR, Zamani P, Behravan J. Crosstalk in cancer resistance and metastasis. Crit Rev Oncol Hematol 2018;132:145-53.

2. Wang L, Bernards R. Taking advantage of drug resistance, a new approach in the war on cancer. Front Med 2018;12:490-5.

3. Gatenby R, Brown J. The evolution and ecology of resistance in cancer therapy. Cold Spring Harb Perspect Med 2018:8:a033415.

4. Haji Fatahaliha M, Hosseini M, Akbarian A, Sadreddini S, Jadidi Niaragh F, Yousefi M. CAR-modified T-cell therapy for cancer: an updated review. Artificial Cells Nanomed Biotechnol 2016;44:1339-49.

5. Stanley J Oiseth, Mohamed S Aziz. Cancer immunotherapy: a brief review of the history, possibilities, and challenges ahead. J Cancer Metastasis Treat 2017;3:250-61.

6. Qian X, Wang X, Jin H. Cell transfer therapy for cancer: past, present, and future. J Immunol Res 2014;52:5913.,

7. Tebas P, Stein D, Tang WW, Frank I, Wang SQ, Lee G, et al. Gene editing of CCR5 in autologous CD4 T cells of persons infected with HIV. N Engl J Med 2014;370:901-10.

8. K Murphy, P Travers, M Walport. Principles of innate and adaptive immunity in Janeway's Immunobiology. 7th edition. Garland Science Taylor and Francis Group, New York: NY, USA; 2008. p. 1-388.

9. Chen DS, Mellman I. Oncology meets immunology: the cancer immunity cycle. Immunity 2013;39:1-10.

10. Tao Z, Li S, Ichim TE, Yang J, Riordan N, Yenugonda V, et al. Cellular immunotherapy of cancer: an overview and future directions. Immunotherapy 2017;9:589-606.

11. MD Vesely, MH Kershaw, RD Schreiber, MJ Smyth. Natural innate and adaptive immunity to cancer. Annual Rev Immunol 2011;29:235-71.

12. Wolf H Fridman. From cancer immune surveillance to cancer immunoediting: birth of modern immuno-oncology. J Immunol 2018;201:825-6.

13. RD Schreiber, LJ Old, MJ Smyth. Cancer immunoediting: integrating immunity's roles in cancer suppression and promotion. Science 2011;6024:1565-70.

14. Hugo Gonzalez, Catharina Hagerling, Zena Werb. Roles of the immune system in cancer: from tumor initiation to metastatic progression. Genes Dev 2018;32:1267-84.

15. JL Adams, J Smothers, R Srinivasan, A Hoos. Big opportunities for small molecules in immuno-oncology. Nat Rev Drug Discovery 2015;14:603-21.

16. Yousef Ahmed Fouad, Carmen Aanei. Revisiting the hallmarks of cancer. Am J Cancer Res 2017;7:1016-36.

17. Anna Meiliana, Nurrani Mustika Dewi, Andi Wijaya. Cancer immunotherapy: a review. Indonesian Biomed J 2016;8:1-20.

18. Rutika Kokate. A systematic overview of cancer immunotherapy: an emerging therapy. Pharm Pharmacol Int J 2017;5:112.
19. Eggermont LJ, Paulis LE, Tel J, Figdor CG. Towards efficient cancer immunotherapy: advances in developing artificial antigen-presenting cells. Trends Biotechnol 2014;32:456-65.

20. Humphries C. Adoptive cell therapy: honing that killer instinct. Nat 2013;504:S13-15.

21. Dronca RS, Dong H. Immunomodulatory antibody therapy of cancer: the closer the better. Clin Cancer Res 2015;21:944-6.

22. Lipson EJ. Re-orienting the immune system: durable tumor regression and successful re-induction therapy using antiPD1 antibodies. Oncoimmunology 2013;2:e23661.

23. Vacchelli E, Eggermont A, Fridman WH, Galon J, Tartour E, Zitvogel L, et al. Trial watch: adoptive cell transfer for anticancer immunotherapy. Oncoimmunology 2013;2:e24238.

24. Luca Gattinoni. Adoptive $\mathrm{T}$ cell transfer: imagining the next generation of cancer immunotherapies. Semin Immunol 2016;28:1-2.

25. Galluzzi L, Vacchelli E, Eggermont A, Fridman WH, Galon J, Sautes Fridman C, et al. Trial watch: adoptive cell transfer immunotherapy. Oncoimmunology 2012;1:306-15.

26. Minda Asfaw Geresu, Awel Feku Sultan, Seifudin Kassim Ahmed, Gezahegne Mamo Kassa. Immunotherapy against cancer: a comprehensive review. J Cancer Res Exp Oncol 2016;8:15-25.

27. Merhavi Shoham E, Itzhaki O, Markel G, Schachter J, Besser MJ. Adoptive cell therapy for metastatic melanoma. Cancer J 2017;23:48-53.

28. Rosenberg SA, Restifo NP, Yang JC, Morgan RA, Dudley ME. Adoptive cell transfer: a clinical path to effective cancer immunotherapy. Nat Rev Cancer 2008;8:299-308.

29. Sharpe M, Mount N. Genetically modified T cells in cancer therapy: opportunities and challenges. Dis Model Mech 2015;8:337-50.

30. Dudley ME, Gross CA, Somerville RPT, Hong Y, Schaub. Randomized selection design trial evaluating CD8+-enriched versus unselected tumor-infiltrating lymphocytes for adoptive cell therapy for patients with melanoma. J Clin Oncol 2013;31:2152-9.

31. Michaela Sharpe, Natalie Mount. Genetically modified T cells in cancer therapy: opportunities and challenges. Disease Models Mechanisms 2015;8:337-50.

32. Dudley ME, Wunderlich JR, Robbins PF, Yang JC, Hwu P, Schwartzentruber DJ, et al. Cancer regression and autoimmunity in patients after clonal repopulation with antitumor lymphocytes. Science 2002;298:850-4.

33. Rosenberg SA, Yang JC, Sherry RM, Kammula US, Hughes MS, Phan GQ, Citrin DE, et al. Durable complete responses in heavily pretreated patients with metastatic melanoma using $\mathrm{T}$ cell transfer immunotherapy. Clin Cancer Res 2011;17:4550-7.

34. Scanlan MJ, Gure AO, Jungbluth AA, Old LJ, Chen YT. Cancer/testis antigens: an expanding family of targets for cancer immunotherapy. Immunol Rev 2002;188:22-32.

35. Rosenberg SA, Packard BS, Aebersold PM, Solomon D, Topalian SL, Toy ST, et al. Use of tumor-infiltrating lymphocytes and interleukin-2 in the immunotherapy of patients with metastatic melanoma. A preliminary report. N Engl J Med 1988;319:1676-80.

36. Besser MJ, Shapira Frommer R, Itzhaki O, Treves AJ, Zippel DB, Levy $\mathrm{D}$, et al. Adoptive transfer of tumor-infiltrating lymphocytes in patients with metastatic melanoma: intent-totreat analysis and efficacy after failure to prior immunotherapies. Clin Cancer Res 2013;19:4792-800.

37. Pilon Thomas S, Kuhn L, Ellwanger S, Janssen W, Royster E, Marzban S, et al. Efficacy of adoptive cell transfer of tumorinfiltrating lymphocytes after lymphopenia induction for metastatic melanoma. J Immunother 2012;35:615-20.

38. Radvanyi LG, Bernatchez C, Zhang M, Fox PS, Miller P, Chacon J, et al. Specific lymphocyte subsets predict response to adoptive cell therapy using expanded autologous tumor-infiltrating lymphocytes in metastatic melanoma patients. Clin Cancer Res 2012;18:6758-70.

39. Sato E, Olson SH, Ahn J, Bundy B, Nishikawa H, Qian F, et al. Intraepithelial CD8+tumor-infiltrating lymphocytes and a high CD8+/regulatory $\mathrm{T}$ cell ratio are associated with favorable prognosis in ovarian cancer. Proc Natl Acad Sci USA 2005;102:18538-43. 
40. Galon J, Costes A, Sanchez Cabo F, Kirilovsky A, Mlecnik B, Lagorce Pages $C$, et al. Type, density, and location of immune cells within human colorectal tumors predict clinical outcome. Science 2006;313:1960-4.

41. Loi S. Tumor-infiltrating lymphocytes, breast cancer subtypes and therapeutic efficacy. Oncoimmunology 2013;2:e24720.

42. Kawakami Y, Eliyahu S, Delgado CH, Robbins PF, Sakaguchi K, et al. Identification of a human melanoma antigen recognized by tumor-infiltrating lymphocytes associated with in vivo tumor rejection. Proc Natl Acad Sci USA 1994;91:6458-62.

43. Harris DT, Kranz DM. Adoptive t cell therapies: a comparison of $t$ cell receptors and chimeric antigen receptors. Trends Pharmacol Sci 2016;37:220-30.

44. Ruella M, Kalos M. Adoptive immunotherapy for cancer. Immunol Rev 2014;257:14-38.

45. Morgan RA, Dudley ME, Wunderlich JR, Hughes MS, Yang JC, Sherry RM, et al. Cancer regression in patients after transfer of genetically engineered lymphocytes. Science 2006;314:126-9.

46. Johnson LA, Morgan RA, Dudley ME, Cassard L, Yang JC, Hughes MS, et al. Gene therapy with human and mouse T-cell receptors mediates cancer regression and targets normal tissues expressing cognate antigen. Blood 2009;114:535-46.

47. Parkhurst MR, Yang JC, Langan RC, Dudley ME, Nathan DA, Feldman SA, et al. T cells targeting carcinoembryonic antigen can mediate regression of metastatic colorectal cancer but induce severe transient colitis. Mol Ther 2011;19:620-6.

48. Robbins PF, Morgan RA, Feldman SA, Yang JC, Sherry RM, Dudley ME, Wunderlich JR, et al. Tumor regression in patients with metastatic synovial cell sarcoma and melanoma using genetically engineered lymphocytes reactive with NY-ESO-1. J Clin Oncol 2011;29:917-24.

49. Rapoport AP, Stadtmauer EA, Binder Scholl GK, Goloubeva O Vogl DT, Lacey SF, et al. NY-ESO-1-specific TCR-engineered T cells mediate sustained antigen-specific antitumor effects in myeloma. Nat Med 2015;21:914-21.

50. Robbins PF, Kassim SH, Tran TL, Crystal JS, Morgan RA Feldman SA, et al. A pilot trial using lymphocytes genetically engineered with an NY-ESO-1-reactive T-cell receptor: longterm follow-up and correlates with response. Clin Cancer Res 2015;21:1019-27

51. Ajina A, Maher J. Strategies to address chimeric antigen receptor tonic signaling. Mol Cancer Ther 2018;17:1795-815.

52. Jensen MC, Riddell SR. Designing chimeric antigen receptors to effectively and safely target tumors. Curr Opin Immunol 2015;33:9-15.

53. Enblad G, Karlsson H, Loskog AS. CAR-T-cell therapy: the role of physical barriers and immunosuppression in lymphoma. Hum Gene Ther 2015;26:498-505.

54. Zhang C, Liu J, Zhong JF, Zhang X. Engineering CAR-T cells. Biomark Res 2017;5:1-6.

55. June CH, O'Connor RS, Kawalekar OU. CAR T cell immunotherapy for human cancer. Science 2018;359:1361-5.

56. Ramachandran M, Cancer Immunotherapy. Evolving oncolytic viruses and CART-cells. Digital Comprehensive. Dissertations from the Faculty of Medicine. Uppsala: Acta Universitatis Upsaliensis; 2016.

57. Scholler J, Brady T, Binder Scholl G. Decade-long safety and function of retroviral-modified chimeric antigen receptor $\mathrm{T}$ cells. Sci Transl Med 2012;4:132ra53.

58. Davenport AJ, Jenkins MR, Cross RS, Yong CS, Prince HM, Ritchie DS, et al. CAR-T cells inflict sequential killing of multiple tumor target cells. Cancer Immunol Res 2015;3:483-94.

59. Letourneur F, Klausner RD. T-cell and basophil activation through the cytoplasmic tail of T-cell-receptor zeta family proteins. Proc Natl Acad Sci USA 1991;88:8905-9.

60. Srivastava S, Riddell SR. Engineering CAR-T cells: design concepts. Trends Immunol 2015;36:494-502.

61. Sadelain $M$, Rivière I, Riddell $S$. Therapeutic T cell engineering. Nat 2017;545:423-31.

62. Kuwana $Y$, Asakura $Y$, Utsunomiya N, Nakanishi M, Arata Y, Itoh $\mathrm{S}$, et al. Expression of chimeric receptor composed of immunoglobulin-derived V regions and T-cell receptor-derived C regions. Biochem Biophys Res Commun 1987;149:960-8.
63. Davila ML, Riviere I, Wang X, Bartido S, Park J, Curran K, et al. Efficacy and toxicity management of 19-28z CAR T cell therapy in B cell acute lymphoblastic leukemia. Sci Transl Med 2014;6:224ra25.

64. Maude SL, Frey N, Shaw PA, Aplenc R, Barrett DM, Bunin NJ, et al. Chimeric antigen receptor t cells for sustained remissions in leukemia. N Engl J Med 2014;371:1507-17.

65. Schuster SJ, Svoboda J, Chong EA. Adoptive immunotherapy with CD19 CAR-T cells. Cancer Discovery 2017;7:1404-19.

66. Long $\mathrm{AH}$, Haso WM, Shern JF, Wanhainen KM, Murgai M, Ingaramo $\mathrm{M}$, et al. $1 \mathrm{BB}$ costimulation ameliorates $\mathrm{T}$ cell exhaustion induced by tonic signaling of chimeric antigen receptors. Nat Med 2015;21:581-90.

67. Frigault MJ, Lee J, Basil MC, Carpenito C, Motohashi S, Scholler J, et al. identification of chimeric antigen receptors that mediate constitutive or inducible proliferation of $\mathrm{T}$ cells. Cancer Immunol Res 2015;3:356-67.

68. Peter J Stambrook, John Mahe, Farzin Farzaneh. Cancer immunotherapy: whence and whither. Mol Cancer Res 2017;16:427.

69. Zijun Zhaoa, Yu Chena, Ngiambudulu M Franciscoa, Yuanqing Zhangb N, Minhao Wu. The application of CAR-T cell therapy in hematological malignancies: advantages and challenges. Acta Pharm Sinica B 2018;8:539-51.

70. Porter DL, Hwang WT, Frey NV, Lacey SF, Shaw PA, Loren AW, et al. Chimeric antigen receptor $\mathrm{T}$ cells persist and induce sustained remissions in relapsed refractory chronic lymphocytic leukemia. Sci Transl Med 2015;7:303ra139.

71. Porter DL. Randomized, phase II dose optimization study of chimeric antigen receptor (CAR) modified $\mathrm{T}$ cells directed against CD19 in patients (pts) with relapsed, refractory (R/R) CLL. J Clin Oncol 2016;34:3009.

72. Zhao J, Lin Q, Song Y, Liu D. Universal CARs, universal T cells, and universal CAR T cells. J Hematol Oncol 2018;11:132.

73. Grupp SA, Kalos M, Barrett D, Aplenc R, Porter DL, Rheingold $\mathrm{SR}$, et al. Chimeric antigen receptor-modified $\mathrm{t}$ cells for acute lymphoid leukemia. N Engl J Med 2013;368:1509-18.

74. Gill S, Maus MV, Porter DL. Chimeric antigen receptor T cell therapy: 25 y in the making. Blood Rev 2016;30:157-67.

75. Nirav N Shah, Theresa Maatman, Parameswaran Hari, Bryon Johnson. Multi targeted CAR-T cell therapies for B-cell malignancies. Frontiers Oncol 2019;9:146.

76. Lee DW, Kochenderfer JN, Stetler Stevenson M, Cui YK, Delbrook C, Feldman S. A. T cells expressing CD19 chimeric antigen receptors for acute lymphoblastic leukaemia in children and young adults: a phase I dose-escalation trial. Lancet 2015;385:517-28.

77. Frey NV, Shaw PA, Hexner EO, Gill S, Marcucci K, Luger SM, et al. Optimizing chimeric antigen receptor (CAR) T cell therapy for adult patients with relapsed or refractory (R/R) acute lymphoblastic leukemia (ALL). J Clin Oncol 2016;34:7002.

78. Matthew H Forsberg, Amritava Das, Krishanu Saha, Christian M Capitini. The potential of CAR $\mathrm{T}$ therapy for relapsed or refractory pediatric and young adult B-cell ALL. Ther Clin Risk Manag 2018;14:1573-84

79. Shalabi H, Angiolillo A, Fry TJ. Beyond CD19: opportunities for future development of targeted immunotherapy in pediatric relapsed-refractory acute leukemia. Front Pediatr 2015;3:80.

80. Mewawalla $\mathrm{P}$, Nathan S. Role of allogeneic transplantation in patients with chronic lymphocytic leukemia in the era of novel therapies: a review. Ther Adv Hematol 2014;5:139-52.

81. Brudno JN. Allogeneic $\mathrm{T}$ cells that express an anti-CD19 chimeric antigen receptor induce remissions of B-cell malignancies that progress after allogeneic hematopoietic stem-cell transplantation without causing graft-versus-host disease. J Clin Oncol 2016;34:1112-21.

82. Kochenderfer JN, Dudley ME, Kassim SH, Somerville RP, Carpenter RO, Stetler-Stevenson M. Chemotherapy-refractory diffuse large B-cell lymphoma and indolent B-cell malignancies can be effectively treated with autologous $\mathrm{T}$ cells expressing an anti-CD19 chimeric antigen receptor.J Clin Oncol. 2015; 33:540-9.

83. Turtle CJ. Durable molecular remissions in chronic lymphocytic leukemia treated with CD19-specific chimeric antigen 
receptor-modified T cells after failure of ibrutinib. J Clin Oncol 2017;35:3010-20.

84. Geyer MB, Park JH, Brentjens RJ. Chimeric antigen receptor-t cells for leukemias in adults: methods, data and challenges. Cell Gene Ther; 2018. p. 75-92.

85. Milone MC, Fish JD, Carpenito C, Carroll RG, Binder GK, Teachey $\mathrm{D}$, et al. Chimeric receptors containing CD137 signal transduction domains mediate enhanced survival of $\mathrm{T}$ cells and increased antileukemic efficacy in vivo. Mol Ther 2009; 17:1453-64.

86. Turtle CJ, Hanafi LA, Berger C, Gooley T, Chaney C, Cherian C. Rate of durable complete response in ALL, NHL, and CLL after immunotherapy with optimized lymphodepletion and defined composition CD19 CAR-T cells. J Clin Oncol 2016;34:102.

87. Brentjens RJ. CD19-targeted T cells rapidly induce molecular remissions in adults with chemotherapy-refractory acute lymphoblastic leukemia. Sci Transl Med 2013;5:177ra138.
88. Fraietta JA, Beckwith KA, Patel PR, Ruella M, Zheng Z, Barrett DM, et al. Ibrutinib enhances chimeric antigen receptor T-cell engraftment and efficacy in leukemia. Blood 2016;127:1117-27.

89. Frey NV. Refractory cytokine release syndrome in recipients of chimeric antigen receptor (CAR) T cells. Blood 2014;124:2296-6.

90. Kochenderfer JN. B-cell depletion and remissions of malignancy along with cytokine-associated toxicity in a clinical trial of antiCD19 chimeric-antigen-receptor-transduced $\mathrm{T}$ cells. Blood 2012;119:2709-20.

91. Lim WA, June $\mathrm{CH}$. The principles of engineering immune cells to treat cancer. Cell 2017;168:724-40.

92. Bonini C, Mondino A. Adoptive T-cell therapy for cancer: the era of engineered T cells. Eur J Immunol 2015;45:2457-69.

93. Duong CP, Yong CS, Kershaw MH, Slaney CY, Darcy PK. Cancer immunotherapy utilizing gene-modified T cells: from the bench to the clinic. Mol Immunol 2015;67:46-57. 